\title{
Remploy
}

Our five binderies located in Barking, Halifax, Stockton, Newcastle-under-Lyme and Ystradgynlais, Glamorgan were designed and equipped to give you an up-to-date service with speedy collection and delivery for your consignments.

University, Research Institutes and Hospital Libraries:-For your journals a really strong binding in good quality materials. Colours and materials to match your present bindings.

A free advisory Service, backed by our Works Managers and our Technical Representatives, all of them with considerable experience in solving problems presented by Librarians.

A consultation with Remploy gives you the opportunity to take a new look at your shelves; with our offer of speedy service and truly competitive estimates it could be well worth your while.

Write or phone Remploy Limited (P. \& B. Room 216), 415 Edgware Road, London NW2 6LR.

Tel: 01-452 8020 (Extension 251).

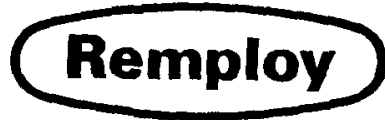

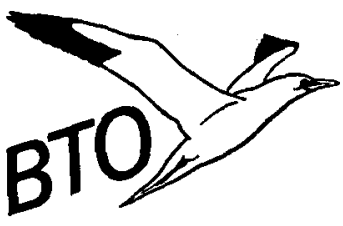

FACTS go hand in hand with FENCES in bird conservation

The British Trust for Ornithology is the organization whose members provide the facts.

MEMBERS can take part in special enquiries, add to the pleasure which they derive from birds by reading the frequent issues of BTO News and the quarterly journal Bird Study or, if they prefer, help support the Trust's aims and work financially.

Ask Chris Salmon for membership details at

BRITISH TRUST FOR ORNITHOLOGY Beech Grove, Tring, Herts. (Tring 346r)

Members joining after 30 th September receive up to I5 months membership for their first subscription. 


\title{
KENDALL TRAVEL SERVICE
}

\section{ORYX TOURS}

\section{for the Fauna Preservation Society}

\author{
FORTHCOMING DEPARTURES
}

ORYX TOUR 15

2 November 1972

ARGENTINA and BRAZIL

Buenos Aires-The Pampas-Tierra del Fuego-Valdes

Peninsula-Iguassu Falls-Rio de Janeiro

$£ 725$

OrYX TOUR 18

26 January 1973

UGANDA and ETHIOPIA

Queen Elizabeth N.P.-Toro Game Reserve-Murchison Falls

N.P.-Kidepo N.P.-Awash N.P.-Langano

Price to be annouced

ORYX TOUR 16

27 January 1973

ARGENTINA and BRAZIL

Buenos Aires-The Pampas-Bariloche-Valdes Peninsula Iguassu Falls-Rio de Janeiro $£ 805$

ORYX TOUR 19

21 March 1973

\section{CEYLON and INDIA}

Ruhuna N.P.-Wilpattu N.P.--Kanha N.P.-Sasan Wankaner-Keoladeo Wildlife Sanctuary-Srinagar Price to be announced

Further information and reservations from

M. K. KENDALL LTD

18/19 Eldon Street

London EC2M 7LP

Tel: (01) 638-0771

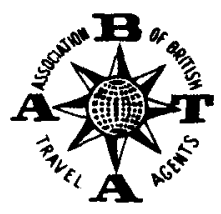




\section{Sea South Africa March to September... when so much is in season}

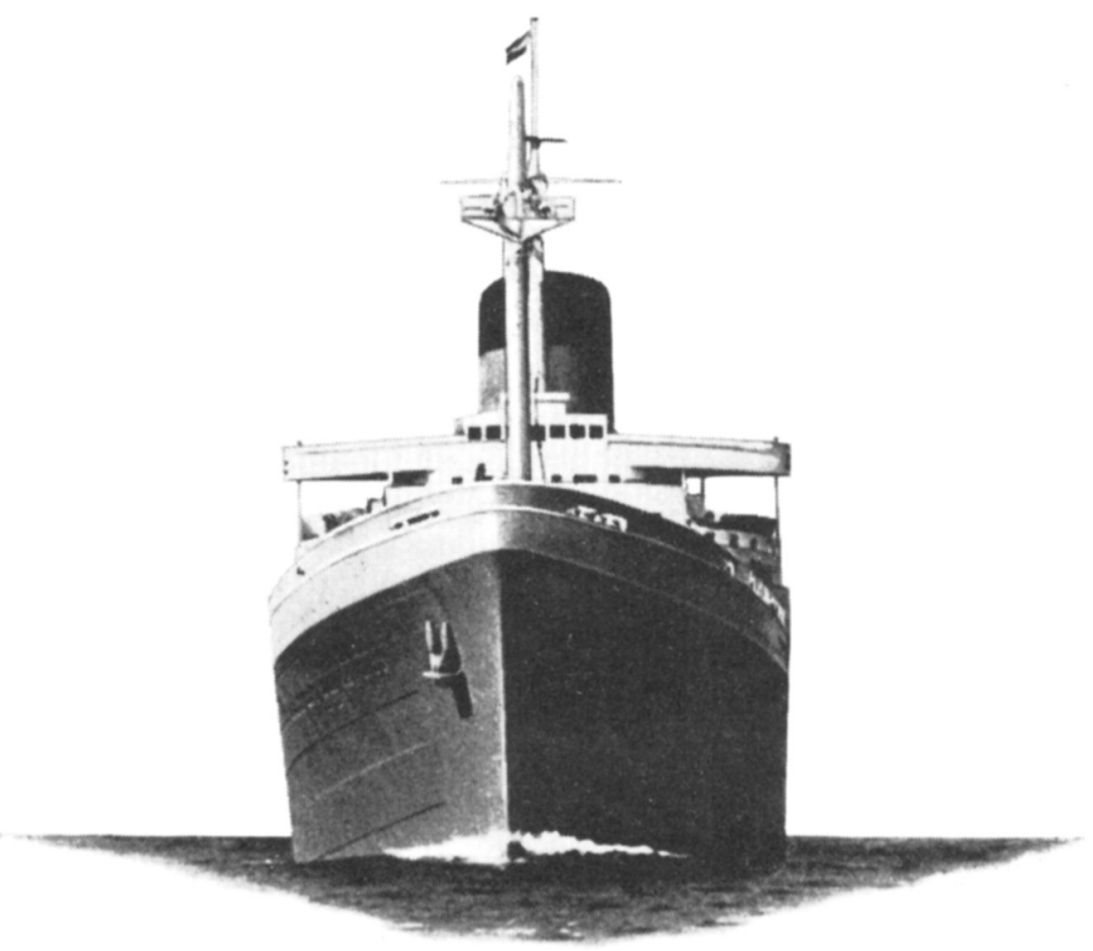

Whatever you want to find in Africa-whether it's the excitement of the vast game reserves, the sheer majesty of Victoria Falls or the floral splendour of the Cape in September-Union-Castle can arrange the perfect holiday for you.

Take a main centre holiday in Cape Town or Durban or go on a breathtaking safari tour. Travel is by luxury liner, scheduled jet or both.

Send off today for our beautifully illustrated brochure on African Holidays, or see your local travel agent.

\section{UNION-GASTLE}

Dept. OM5 I9/2r Old Bond Street, London, WIX ${ }_{4}$ AN Telephone: or -4938400 


\section{Zesmbia}
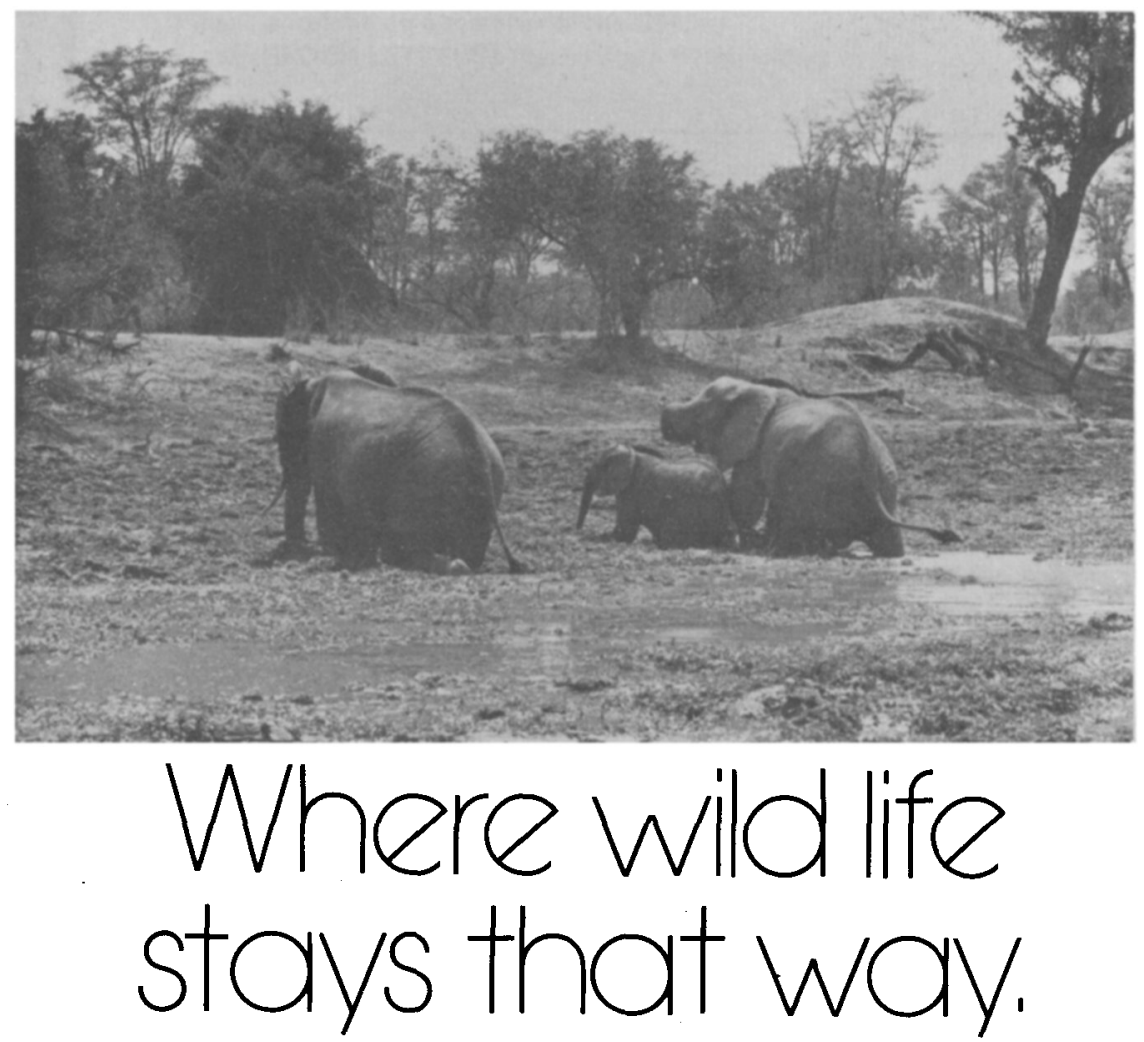

Nowhere else in Africa is conservation taken so seriously as in Zambia. To us, conservation means protecting our fauna from that most dangerous of predators-man-whilst preserving their natural habitat and maintaining the ecological balance.

Zambian wild life is completely free, uniquely unspoilt, staggeringly profuse and diverse. The vast game parks which keep it that way are a naturalist's paradise.

Come and see them.

Zambia national tourist bureau 163 Piccadilly, London W.1. Tel: 01-493 5552 


\section{THE}

\section{SLADMORE}

\section{GALLERY}

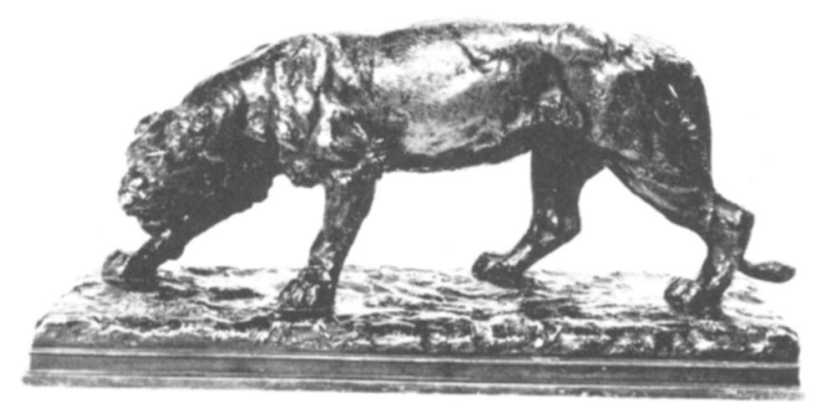

"ROYAL" TIGER

by

\section{ISIDORE JULES BONHEUR (1827-190r)}

Signed, in bronze $6^{\prime \prime} \times 12^{\prime \prime}$

Exbibition I 8th October-I Ith November 1972

$$
\text { of }
$$

Recent Paintings by

TERENCE CUNEO

Painted in England and the Carmargue

32 BRUTON PLACE, LONDON W.I

Tel: or-499 0365 


\section{Application for Membership}

\section{The Fauna Preservation Society}

c/0 The Zoological Society of London, Regent's Park, London NW1

Please enrol me as a member of the Society

Name (BLOCK LETTERS) Please state Mr/Mrs/Miss or title

Address

lenclose $\&$ : :

being my subscription as a Life/Benefactor/Ordinary Member.

The minimum subscription for Ordinary Members is £3, US \$7.75, for Benefactors $£ 10$, US \$25, payable on January 1st. A Banker's Order saves time, expense and reminders. The value of any subscription is greatly increased if it is paid under a seven-year Deed of Covenant (UK standard-rate income taxpayers only) and this entails no extra cost whatever: write for Covenant forms to the Secretary.

Life membership fees:

Age: Under 41, £200, US \$485; age 41-60, £150, US \$365; age 61 and over, $£ 75$ US \$185.

\section{Banker's Order}

Bank

Address of Bank

Please pay for the Credit of The Fauna Preservation Society, Barclays Bank Ltd,, Camden Town, London NW1, my subscription of $£ . . .$. due on 1 st January, 19 , and a similar amount on 1 st January each year until further notice. 


\section{Special Interest Tours by PEREGRINE HOLIDAYS}

\section{Natural History-Spring}

CRETE . . . . 4th successful year and advance bookings make two parties necessary. East/West has Allen Paterson, N.D.H. (flowers-3rd year) and Derek Lucas (birds-2nd year). West/East Tour has Dr. Mary Gillham (flowers) and Dr. Jo Hambury (birds-2nd time with us).

$$
\text { Depart April 2 . . ...16 days . ... £171.00 }
$$

CYPRUS . . . . . Last year's successful tour with Dr. David Lack and Patrick Synge, M.A., is repeated this year with fewer centres thus obviating tiresome packing. Dr. Christopher Perrins (birds-2nd time with us). Kenneth Burras, N.D.H. (flowers-2nd time) as botanist. Depart April 3 ..... Is days . . . . $\mathbf{1 8 9 . 0 0}$

TURKEY-SOUTHERN ... . . 3rd successful year touring all the major sites (including APHRODISIAS and TERMESSUS), the tour has now been given a full Natural History quality. Sir Hugh Elliott, Bart., (birds). Leonard Beer-flowers.

Depart May 9 . . . 15 days . . . . $\$ 219.00$

TURKEY-EASTERN . . . . This daring and unique adventure went off to a flying start last year with Anthony Huxley and John Gooders, drawing participants from many countries. The beauty of Lake Van and its masses of pelicans, the huge irises in the Ararat foothills, Rosefinches at the "lost" village of ISTAVRI and Rose-coloured starlings at ANI add up to an astonishing experience. Not for fainthearts-but age has nothing to do with it. Guest lecturers to be announced later.

Depart June 6 . . . . 16 days . . . . $\$ 251.00$

\section{Natural History-Autumn}

ETHIOPIA . . . . Completely new tour inspired by many requests for a tour of this marvellous country. Anthony Huxley, M.A., will be guest lecturer for botany and it is hoped that an ornithologist of similar international stature will also be available.

Depart mid October . . . . . 18 days . . . . $\mathbf{\$ 3 5 0 . 0 0}$

\section{Special Classical Study Tour-Spring}

MAINLAND GREECE AND PELOPONNESE . . . . . Once again under the dynamic leadership of Dr. Pinsent this tour repeats the success of 1972. Although mainly concerned with the sites of Classical Antiquity these sites themselves are veritable rock gardens and bird sanctuaries (rock nuthatches) and the tour gives a chance to those more leisurely naturalists who are perhaps not considered often enough.

Depart April 4 . . . 15 days . . . . £169.00

\section{Autumn "Follow Up" Tours}

GREECE, CRETE, CYPRUS, TURKEY. Late September early October. Guest lecturers will include Dr. C. Kraay, Dr. A. Bryer, Dr. J. Pinsent, Dr. and Mrs. P. Wade-Martins and Miss Sue Boyd from Dumbarton Oaks, Washington D.C. Itineraries and prices similar. Ideal for those who are as much interested in antiquities as in

Natural History. Advance registrations carry no obligations.

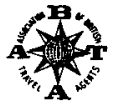

\section{All tours by Scheduled Air Services of IATA Carriers}

Peregrine Holidays at Town \& Gown Travel 41 South Parade, Summertown, Oxford OX2 7JP

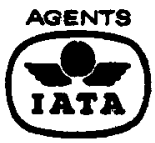

Tel. Oxford 54517 \& 55345 


\section{THE MOORLAND GALLERY LTD}

23 CORK STREET, BOND STREET, LONDON, W.1 (01-734 6961)

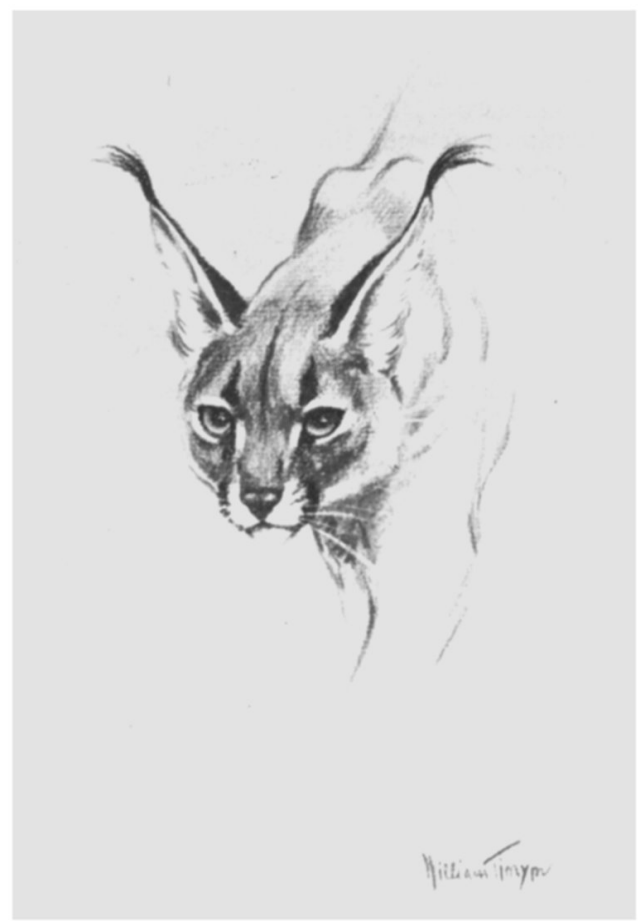

Specialists in NATURAL HISTORY Pictures, Prints and Bronzes

MON.-FRI. 9.30 a.m.-5.30 p.m. 


\section{FPS Wildlife Film Library}

Unless otherwise stated all films are $16 \mathrm{~mm}$. in colour with sound track and cost $f I$ each to hire. To book a film please write to the Films Officer, Fauna Preservation Society, c/o Zoological Society, Regent's Park, London NWI 4RY. Tel.: or 5860872.

The Uganda Kob - Territorial and mating behaviour, by H. K. and J.H. Buechner. Presented by the Smithsonian Institution. 20 mins. $£ 2$.

The Last of the Wild, by Eugen Schuhmacher. r ro mins. f,Io.

Wildlife for the Future, by Gordon Maclean. 20 mins. $£ 2$. New film on work of a county naturalists' trust.

Saiga Saga. Life history and conservation of the saiga antelope, Russian commentary with English titles. 16 minutes. Presented by the Soviet Peace Committee. Charge $£ 2$.

Koala, by H. J. Pollock. Complete life history. 24 minutes. Charge, $£ 2$.

Marloo, The Red Kangaroo, by H. J. Pollock. 25 minutes. $\ell_{2}$.

The Seals of Macquarie Island. Elephant and fur seals. I2 minutes.

Penguins of Macquarie Island. King, gentoo, rockhopper and royal penguins. 13 minutes.

The Mallee Fowl. The remarkable nesting story of a 'mound-builder'. I I minutes.

Le Aye Aye de Madagascar, by J. J. Petter. Black and white, French commentary, 22 minutes. Presented by the Service du Film de Recherche Scientifique.

The Silent Watcher, by Eric Ashby, commentary by Peter Scott. Badgers, deer and foxes in the New Forest. Black and white, 35 minutes. fI.50.

Escape to Samburu. Wildlife of a reserve in Northern Kenya. 40 minutes. Presented by the Munitalp Foundation. $£ 2$.

Lake Wilderness. Wildlife of St. Lucia Lakes. 20 minutes, and

To Catch a Rhino. 20 minutes; $f_{2}$ each. South African Tourist Corp.

The African Lion, by A. I. M. Hepburn. Taken in the Kruger National Park. Magnetic sound track. I2 minutes.

The Swallowtail Butterfly. The complete life story. 25 minutes. £2.

A Million Flamingos, by Hugh Cressy-Hall. I2 minutes.

Wildlife in Trust, by Gordon Maclean. The work of a Naturalists' Trust (Berks, Bucks and Oxon). 25 minutes. $£ 2$.

South Africa's Animal Kingdom. 20 minutes. S.A. Tourist Corp. £2.

Wildlife in Danger. Commentary by Peter Scott. 21 minutes. f2. $^{2}$

The Rain Forest, by Tom and Barbara Harrisson. Mainly about orang utans. Black and white, 27 minutes.

Wild Life in Uganda. 12 minutes.

Down in the Forest. Kangaroos. 6 minutes. (For children).

Kaziranga Sanctuary, Assam. Two films, each II minutes; similar material.

Birds of East and Central Africa. 45 minutes. $£ 2$.

\section{Silent Films with Captions}

Ceylon Wildlife, by C. E. Norris. Written commentary. 50 minutes.

Operation Oryx, by Michael Woodford. The FPS expedition. Black and white, 30 minutes.

The African Elephant. Io minutes. 


\section{Contents}

Page

Notes and News

403

Project Tiger

413

Tiger Census

Richard Waller

Fifty Years of ICBP Jean Delacour

Briefly. . .

Richard Fitter

Conservation by Utilisation

Michael Crawford

Iran Guards its Wildlife

Progress and Problems in Colombia

Roger Perry

Colombia's National Parks

Don Hunsaker //

Vicuña in Argentina

$$
\text { Jeffery Boswall }
$$

Rhinos in Thailand Jeffery A. McNeely and Edward W. Cronin

A National Parks System for West Malaysia Bruce E. Weber

Mammals in Nigeria

David Happold

Ghana's Progress

E. O. A. Asibey

Book Reviews

Reports and Journals 
Printed in Great Britain by

Alden \& Mowbray Ltd

at the Alden Press, Oxford 